\title{
Education and Training of Volleyball Information System (VIS FIVB) Based Volleyball Playing Performance Assessment Program for Volleyball Coaches in West Java, Indonesia
}

\author{
Yunyun Yudiana*, Suherman Slamet and Burhan Hambali \\ Physical Education Departement \\ Universitas Pendidikan Indonesia \\ Bandung, Indonesia \\ *yunyunyudiana@upi.edu
}

\begin{abstract}
This program aimed to build and stabilize knowledge, understanding, and skill of volleyball coaches in applying volleyball information system (VIS) based volleyball playing performance assessment program. As much as 40 volleyball coaches were participated in this program that were spread in 24 Cities or Districts in West Java. The outcomes of this program were; (1) Instrument model which could be applied by volleyball coaches to measure athlete's capability when facing VIS based competition; (2) Coaches who have knowledge, understanding, and skill in analysing athlete's performance while playing with VIS based performance assessment program; (3) Coaches who have knowledge, understanding, and skill in interpreting data of VIS based performance assessment for this could be a good feedback for the athlete's performance. After holding training, the results showed that in general, coaches got enlightenment about assessment process while playing volleyball using VIS software. About $60 \%$ of the participants had not known about VIS based assessment process and the rest $40 \%$ of the participants had known the VIS based assessment process yet still not able to apply it with VIS software. Therefore, the conclusion of this submission program was that it gave affect positively on the knowledge and understanding of the coaches in assessing the athletes' skills while playing. Thus, it is expected to having the ability to analyse the data from assessment to become a meaningful feedback for every student, athlete, and even for coach.
\end{abstract}

Keywords: education and training, volleyball information system, volleyball

\section{INTRODUCTION}

Volleyball game is one of the physical activities that is included in game and sports activities [1]. Therefore, volleyball game becomes one of the sports that popular among the society. This is proved with the many volleyball sports clubs that are established as a process of development and production of volleyball athletes in the long run. One barometer that can be made as a reference is Bandung city, where a number of 11 coaching clubs are recorded in PBVSI and they do coaching and producing volleyball athlete.
Coaching factor becomes very crucial and should be a concern for every administrator in sports field to get high achievement, which is considered a challenge in national sports field [2]. This means that when the right coaching systems have been done very well, then great achievement awaits. One of the very basic things in an attempt to fix sports coaching, especially volleyball, is the role and ability of a coach during the training process and also the competition.

A test and measurement in coaching process becomes another important indicator. This is supported by Morrow, et al, who stated that measuring sports skills and motoric abilities are the fundamental aspects from measuring someone's appearance [3]. Thus, the very important thing is that how the coach's ability in conducting test, measuring, and evaluating his athlete, and then this could be a reflection or feedback for both of the athlete and the coach during coaching process. On the other side, the coach's comprehension of the test instrument which will be used in measuring process should be in line with the needs. Also, on the practical level, coaches pay less attention on the test and measurement that causing the coach to not having enough feedback for the athletes' weaknesses and strengths.

An instrument that can be applied by coach to measure or assess performance in volleyball sports is Volleyball Information System (VIS), developed by FIVB in 2005. The instrument is a program completing a match which involves statistics of each player and team. The main purpose of VIS is to inform national and international media of statistics results of team and individual matches [4]. Besides, the result of a research and development done by Yudiana, Hidayat, Slamet \& Hambali, was an assessment instrument of performance which was a modification of the VIS FIVB instrument [5]. The instrument was expected to be able to apply for assessing the athlete's ability when playing volleyball during the practicing process or during competition.

In the point of view of measurement of movement skills mastery, there are two main objectives orientation, which are measuring the quality of hit and quality of movement. The test made for measuring the results of quality of hit included as 
practice) was the method used in the series of activities in the implementation stage. Theory method was conducted by faceto-face meeting like lecture, question and answer, and discussion. Whilst the practice method was in a form of VIS based simulation of performance assessment program, whether in the form of software or manual. The following are the stages of VIS Program Training, presented in detail.

\section{A. Preparation Stage}

The preparation stage is the initial stage before education and training are given. This stage consists of three main steps, which are: (1) The development of work reference, (2) The development of work success instrument, (3) Licensing management administration and the main interviewees [9].

\section{B. Implementation Stage}

Implementation stage is a stage of education, practice, and evaluation. The main purpose of this stage is to give knowledge, understanding, awareness, and skills to coaches about the concept of VIS based volleyball performance assessment program. This event was held on $18-19$ August 2019, in the Faculty of Sports and Fitness Education and Gymnasium of Universitas Pendidikan Indonesia. This education and training program was expected to be able to build coaches' commitment to run the VIS program. Series of activities in this implementation stage are face-to-face session in class, workshop/simulation, program trial, and written and practiced evaluation. Stages in the implementation stage would be explained further more on the discussion.

\section{Evaluation}

Evaluation means assessing the success of the activity using the measurement based on mastery of cognition and practice of preparing and implementing programs in the field. Evaluation on cognition would be done twice, that was before the pre-test, and at the end of the fourth day. The dimensions of the measured aspects of cognition include aspects of knowledge, understanding, and application. The three aspects were then developed into 20 multiple choices questions, which were accommodated from materials given during the event.

The practice evaluation was given in the form of assessment from relevant mentor who has the capability of understanding and practicing VIS based assessment program using computer or manually. The assessment was done while the participants did the VIS based program trial and assessment implementation when observing the players.

\section{RESULT}

According to the discussion on previous chapter, the targets of this community submission program were; (1) Instrument model which could be applied by volleyball coaches to measure athlete's capability when facing VIS based competition; (2) Coaches who have knowledge, understanding, and skill in analysing athlete's performance while playing with VIS based performance assessment program. Next, those two achievements were obtained based on evaluation cognition, while the practice of implementing the VIS assessment program was obtained based on the ability in understanding and practicing VIS based assessment program using computer or just manually when the participants did program trial and the 
implementation of VIS based assessment while observing the athletes.

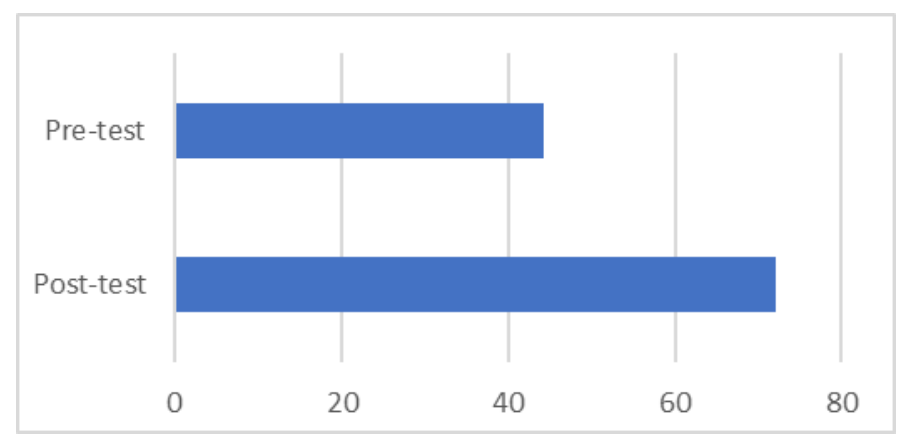

Fig. 2. VIS Achievement Result

The results obtained were that the analysis result of cognitive score pre-test was 44,28 and post-test was 72,7 on average, with the development of percentage average of $67,9 \%$. Meanwhile, the average of practice score was 82,35. The evaluation results in general were that the training had been held, the coaches got enlighten about the process of assessment while playing volleyball using VIS software. As much as $40 \%$ participants had not even know about the VIS based assessment, and the rest $60 \%$ of the participants had known about the VIS based assessment but still could not implementing it using VIS software. Therefore, this program gave a quite significant impact towards education and ability in implementing VIS program using computer application or just did it manually.

\section{IMPLICATION}

The implication is where the VIS based assessment program is implemented in learning or training in a club or school for six two 12 meetings. This is intended to implement the coaches' knowledge after doing the activity. Hopefully it can be implemented when they are coaching players. Therefore, after holding programs in the clubs or schools, every participant was obligated to make a report during the execution in the clubs by making analysis of strengths and weaknesses in implementing VIS program.

This implication will be implemented by the participants in club or school. That is why, after finished practicing, the main expectation is that the target mentioned in the achievement of community submission is achieved, that is the production of volleyball coaches who have knowledge, understanding, and skills in analysing the players while playing with VIS based performance assessment program and also the production of coaches who have knowledge, understanding, and skills in interpreting data from VIS based analysis results.

\section{CONCLUSION}

The result after holding training was that in general, the coaches got enlighten about the assessment process while playing volleyball using VIS software. As much as $40 \%$ participants had not known about the VIS based assessment process at all, and the rest of them (60\%) had known about the VIS based assessment process but still not know how to apply with the support form VIS software. That is why, to sum up, this submission program affected positively on the knowledge and understanding of coaches in assessing the players' ability while playing that the expected main achievement was that the ability to analyse the assessment final results become meaningful feedback to students, athletes, or coaches.

\section{REFERENCES}

[1] Y. Yudiana, "Implementasi Pendekatan Taktik dan Teknik dalam Pembelajaran Permainan Bola Voli pada Pendidikan Jasmani Siswa Sekolah Menengah Pertama," Atikan Jurnal Kajian Pendidikan, vol. 5(1), pp. 95-114, 2015.

[2] S. Purwanto, Danardono, and S. Nopembri, "Pembinaan Prestasi Karate di Daerag Istimewa Yogyakarta," Jurnal Iptek Olahraga UNY, vol. 11(2), 2009.

[3] J.R. Morrow, A.W. Jackson, J.G. Disch, and D.P. Mood, Measurement and evaluation in human performance. (3rd Edn). Canada: Human Kinetics, 2005.

[4] Staff Guidelines, FIVB Volleyball Information Sysytem. Handbook, 2005.

[5] Y. Yudiana, Y. Hidayat, S. Slamet, and B. Hambali, Pengembangan Model Instrumen Perfomance Assessment Berbasis Volleyball Informatios System (VIS) Pada Pembelajaran Bolavoli di Sekolah. Laporan Hasil Penelitian Hibah Penguatan Kompetensi LPPM UPI, 2016.

[6] M.D. Miller, R.L. Linn, and N.E. Gronlund, Measurement and assessment in teaching. New Jersey: Pearson Education Ltd., 2009.

[7] Guide Manual VIS, 2015, Retrieved from:. https://cevadmin.cev.eu/Administration/BeachVolley/EditorImages/547/ fivb_vis_user_manual.pdf.

[8] R.S. Weinberg and D. Gould, Foundation of sport and exercise psychology. (4rd). Auckland: Human Kinetics, 2007.

[9] Y. Hidayat, D. Budiman, and H. Firmansyah, Pendidikan dan Latihan Pemantapan Profesionalisme Pelatih Bulutangkis Melalui Program Intervensi Latihan mental. Laporan Pengabdian Kepada Masyarakat LPPM UPI, 2007. 